\title{
THE ORIGIN OF FIQH SCHOOLS IN AL-ANDALUS: FROM QAIRAWAN TO MEDINA
}

\author{
Muhammad Akmaluddin \\ Mr., MA, State Islamic University Sunan Kalijaga, Indonesia, muhammadakmaluddin@gmail.com
}

\begin{abstract}
The development of Islam in Mashriq at the beginning of second/eighth century until third/ninth century was becoming golden age of knowledge. In al-Andalus, two centuries were used to find intellectual identity on Iberian peninsula. The scholars of al-Andalus did intellectual journey (rihla 'ilmiyya) to Mashriq through several intellectual cities. From Shām, Andalusian scholars followed al-Auzā'î school, which became official school of the Umayyad dynasty in the early days of 'Abd al-Raḥmān al-Dākhil. The provocative cities and the cause of conflict for al-Andalus was Iraq region such as Baghdād. As capital city Abbasid dynasty, the rival of the Umayyad, Baghdād and other Iraq cities were not well-intentioned for learning. Some scholars who learned from Iraq and then returned to al-Andalus were forbidden to spread their ideas, schools and books that brought from Iraq. This led Andalusian scholars to seek the center of knowledge in Medina, the city that was considered supporting Umayyad dynasty in al-Andalus. This intellectual network of Medina caused many scholars in al-Andalus became followers of Mālikī school. Later Mālikī school dominated in al-Andalus by replacing al-Auzā'ĩ school. The scholars also took the route of knowledge from Qairawān, as agency area before going to Medina. The scholars of Mālikĩ school, supported by the Umayyad's government, got authority to ban and censor other schools and books that were incompatible with Mālikiyya. The society of alAndalus under the rulers of Mālikī school only used and made the Qur'an and Muwatța' Mālik as the only references of knowledge. The figh network in al-Andalus will determine the types of scientific studies, books and also style of thought that can be studied and learned over there.
\end{abstract}

Keywords: al-Andalus, Mashriq, Mālikī school, fiqh, Muwațta' Mālik.

\section{ISLAM AND KNOWLEDGE IN AL-ANDALUS}

The development of Islam in Mashriq at the beginning of $2 n d / 8$ th and 3rd/9th century reached golden age of knowledge. While some areas of Africa and al-Andalus were still fought to find its own intellectual identity. This situation caused a very deep gap on level of knowledge and culture between Mashriq and Maghrib. The conquest of al-Andalus by Țāriq bin Ziyād at 93/713 indicated the distance of a century from Prophet's migration to Medina. The conquerors of al-Andalus belonged to none of companions (șahabah) of Prophet 
PBUH, while the number of their successors (tābiîn) was only 28 people. This situation was far away from the conquest of Iraq with the number of 291 companions and 596 successors, in Syria with the number of 108 companions and 35 successors, in Egypt with the number of 31 friends and 5 successors, and in Africa with a total of 25 companions and 24 successors (Husain, 2007, p. 188-189).

The earliest historical codification of the early Mashriq was Iraq at $40 \mathrm{H}$ and the latest was in Egypt at $128 \mathrm{H}$. The earliest historical codification in al-Andalus dated in 238/852. This suggested that the oldest distance of knowledge codification between Mashriq and al-Andalus was 118 years, whereas the shortest distance was 36 years (Husain, 2007, p. 193). The comparison among conquerors and codifications on Mashriq and alAndalus did not make a simple and detached area of knowledge development. To bridge the gap, the scholars of al-Andalus did intellectual journey (rihla 'ilmiyya) to Mashriq through several intellectual cities such as Baghdad, Damascus and Medina. In addition on scientific and cultural factors, the journey was ordered by the rulers of al-Andalus. Al-Maqqarī recorded two major paths of the journey, the people of alAndalus which went to Mashriq and Mashriq people who went to al-Andalus (Al-Maqqarī, 1997). The journey further would determine reality and reflection of people's knowledge in al-Andalus.

The development of knowledge and teachings of Islam, especially hadith and jurisprudence in al-Andalus, could be seen from the role of $q \bar{a} \underline{d} \bar{i}$ (judge). They learnt hadith and taught it to others through their mission (Öztoprak, 2013a). A person must be a faqih (jurist) and muhaddith so that he/she could be recommended to be qāọī. They studied hadith and then developed it to the study of jurisprudence. It started since the time of 'Abd al-Malik bin Habīib (d. 238/852), which spread hadith to al-Andalus (Öztoprak, 2013b). The scholars in al-Andalus had various social roles such as intellectual, religious life guards of society, lawyers, and also they became merchants and craftsmen. They functioned as mediator between the political elite, the tribe and the general public, particularly through religious and legal activity (Rozi, 1983).

The role and the function were running through several decisions and legal doctrines issued by qādīs through their developed school and opinions. This could be seen from which schools and scholars they traveled. Therefore, by knowing each local school in intellectual journey, their thinking, and the knowledge that could be studied, one will understand more comprehensively the essay of the book and also the style of thought in al-Andalus. This paper will discuss schools derived from intellectual journey by Andalusian scholars. Their journey to several cities brought various knowledge of jurisprudence and its impact on knowledge, tradition and authority. Schools of intellectual journey would begin from Shām as the first figh area coming in al-Andalus. Medina and Iraq became the second school of figh after Sham got authority and knowledge degradation, while Qairawān became a bridge connection between al-Andalus and Mashriq in the intellectual journey.

\subsection{Shām School}

Many scholars during the early Umayyad dynasty in al-Andalus came from Shām. Therefore, most of them embraced Auzā'ī school (Amīn, 2012, III, p. 491). The founder of this school was 'Abd al-Rahmān bin 'Amr bin Yahmid al-Auzā'̄. He was born at 88/706 in Ba'labakk and brought by his mother to Beirut. He died in 157/773. Al-Dhahabī said that Auzā'i became the official school in al-Andalus until c. 220/835. After that, the school was diminished from time to time until it was replaced by the Mālikī school. In Damascus, Auzā'i school still existed at c. 340/951 (al-Dhahabī, 2003, IV, p. 120-130; 'Asākir, 1995, XXXVIII, p. 147).

The first man who spread hadith in al-Andalus, according to Ibn al-Faradīi (d. 403/1012) was Șa'șa'ah bin Sallām (d. 180/796) from Syria. He learned from Imām al-Auzā'ì and gave a fatwa at the time of 'Abd alRaḥmān I (756-788) until the time of Hishām bin 'Abd al-Rahmān (788-796). His students included 'Abd alMalik bin Ḩabīb, Uthmān bin Ayyūb and others (Ibn al-Faraḍī, 2008, I, p. 278). W.M. Watt said that in the early days of 'Abd al-Rahnmān I, the number of politicians more than jurists. Al-Auzā'T, who became leader of jurists in all areas of Umayyad before its fall, should be followed by all residents, including al-Andalus as Umayyad area. Likewise, when Umayyad in Damascus fell and al-Andalus became independent regions (Watt \& Cachia, 1977, p. 63-64).

Beside Șa'șa'ah, there was Zuhair bin Mālik al-Balwī (d. circa 250/864). Zuhair was considered as a follower of the last Auzā'i school in al-Andalus. He had argued with 'Abd al-Malik bin Habīib, one of the leaders of the Mālikī school. Because of following Auzā‘'̄, he was discredited from social interaction and knowledge. Zuhair lived among regions Bājah (Beja) and Faḥ̦ al-Ballūṭ or Bațūj (Valle de los Pedroches) where he gained a special part of his grandfather there, 'Adī bin Jadhīmah, at the time of' 'Abd al-Rāḥmān I (Ibn al-Faraḍī, 2008, I, p. 216). After 132/750, al-Auzā'T received the reconciliation of the Abbasid dynasty in Beirut. This caused many scholars and politicians in al-Andalus were not interested yet in following him. The pupils were still many who came to listen to lectures of al-Auzā'i while others went to Medina and other places (Watt \& Cachia, 1977, p. 64). 


\subsection{Medina School}

Abbasid in Mashriq, which replaced Umayyads, moved the central government to Baghdad and made Hanafi as the official school of government. As a result of the policy of Abbasid dinasty, center of Auzā'i school in Damascus was dim and replaced by Hanafī school. In addition, al-Auzāī himself received reconciliation from the Abbasid dynasty. This political situation caused Andalusian people faced two choices of seeking knowledge, to Baghdad and Shām or to other cities like Medina. Some of them later sought knowledge to Baghdad, some went to Medina. They who did not act intellectual journey beyond al-Andalus learned from the scholars who had come from Mashriq.

This situation made the scholars of al-Andalus to seek other center of knowledge. Medina was considered more suitable because of supporting the Umayyad dynasty in al-Andalus (Al-Maqqarī, 1997, II, p 10; III, p. 230). Intellectual networks of Medina made many scholars in al-Andalus became Mālikī followers. The Mālikī school then became more dominant in al-Andalus and replaced school of Auzā'ì. The leaders of al-Andalus scholars who took from Malik, such as al-Ghāzī bin Qais, Shabțūn and Yahyā̄ bin Yaḥā al-Laithī, later became qāọīs. Many qāọīs of Mālikĩ made Mālikī as the official school of the government by Hishām bin 'Abd al-Rahmān (171-179/788-796). Later its policy strengthened by al-Hakam bin Hishām (179-206/796-822) that determined the fatwa with Mālik opinion throughout Cordoba and al-Andalus region (Al-Maqqarī, 1997, III, p. 230).

There were similarities between textual styles of Mālikī and Auzāì schools (Watt \& Cachia, 1977, p. 64). Those who came to Medina studied Muwatța' Mălik that contain about many of Medina people in their worship practices and interaction since the time of Prophet PBUH until the period of Mālik. There were many scholars of al-Andalus who learned from Mālik such as Yahyā bin Yahyāa al-Laithī, who later became the most popular spreader of Muwațta' Mālik in Mashriq and Maghrib (Raisuddin, 1992). Since Mālikī was becoming official school in al-Andalus, the other schools were prohibited and not allowed to enter or learn (Hourani, 1970). In 2nd/8th and 3rd/9th century, Mālikī school made the basics of their schools and Muwatta' Mālik as the main reference wtih the various opinions produced from their predecessors. Other Māliki legal opinions and others that did not based on Muwatța' Mālik were considered as illegal (Fierro, 2011, p. 75-76). This period was also a period of Mālikī introduction. It replaced Auzā'i school that no longer matched with Umayyad dynasty in al-Andalus (Masud, 1991).

\subsection{Iraq School}

Baghdad became provocative area of intellectual journey and caused some conflicts later in al-Andalus. But it still needed and demanded by some Andalusian scholars. As capital city of Abbasid dynasty, Iraq was considered unfit to be a learning decision. In addition, textual styles (ahl al-ḩadïth) of Auzā'i school in alAndalus, which became the official school of early government, were very different from the school of rationalist (ahl al-ra'y) by Hanafī and Shāfi'i schools. Political conflict and rivalry between both Islamic dinasties affected the intellectual conflict. Some scholars who learned from Iraq and then returned to alAndalus were forbidden to spread their ideas and books. The knowledge and culture of Iraq was not feasible and not suitable for al-Andalus (al-Ishbiili, 1988, I, p. 567). Among the scholars who did intellectual journey to the Iraq was Baqi bin Makhlad. He brought a lot of books that did not match with Mālikī school as Muṣannaf Ibn Abī Shaiba, Tārikh Khalîfa bin Khayyāț and others from Baghdad.

Baqī bin Makhlad (d. 276/889) studied in al-Andalus for the first, and then went to Basra in searching knowledge, especially on hadith. He taught Mușannaf Ibn Abi Shaibah that considered had contradiction with Muwatța' Mālik by jurists of al-Andalus. Conflicts between Baqī bin Makhlad and Mālikī scholars made him to be reported to Muhammad bin 'Abd al-Rahmān (238/852-273/886). But he was allowed to spread his ideas and books in al-Andalus by Muhammad bin 'Abd al-Rahmmān (Raisuddin, 1991). Baqī rejected orthodoxy of Mālikī scholars and sole opinion of Muwatța' Māli. He offered to read and consider other books in addition to Muwatța' Mālik, but this led to a strong reaction from Mālikī scholars. He also had conflict and enmity with Mālikī scholars such as Muhammad bin Waḍ̣āḥ and Qāsim bin Aṣbagh. Students of Muḥammad bin Waḍ̂āh, which was also hadith spreader in al-Andalus, were never reported from Baqi because he dan Ibn Waḍdāḥ were in enmity and hostility (Ibn al-Faraḍī, 2008, I, p. 143-146). Așbagh bin Khalīl (d. 273) had strict attitude in Mālikī opinion and did not like hadiths. He said it was better his body chest was filled with wild pig than Musnad Ibn Abī Shaiba, the book narrated by Baqī bin Makhlad (la an yakūna fì tābūtī ra's khinzīr ahābb ilayya min an yakūna fïhi Musnad Ibn Abī Shaiba). He was also at war with Baqī, even though both of them were neighbors. His son, Qāsim bin Așbagh, was forbidden to hear and learn hadith from Baqī (Ibn alFaraḍi, 2008, I, p. 129-131) 


\subsection{Qairawān School}

Qairawān became intermediate areas before going to Mashriq. For example Baqī bin Makhlad and Muḥammad bin Waḍḍāḥ for the first settled in Qairawān before going to Iraq. As said by al-Ṣabbāgh (2011), they learnt from the most popular scholar there, namely Sahnūn bin Sa'íd (d. 240/854), who issued alMudawwana, a book about some questions and answers from Mālikī school. Qairawān became transit place and media of knowledge between al-Andalus and Mashriq. There were ideological relations between alAndalus and Qairawān residents. Some scholars of al-Andalus with their students were been visit central thought of Qairawān. Both regions were interdependent each other in various thoughts. Qairawān had long history for the enrichment of academic movements for the Maghrib region, especially al-Andalus.

Sahnūn was from Ḥimș, Shām and he started to go to Africa in 171/787. Later he went to Egypt in 178/795 to learn and then go to Hijāz. Due to the costs and needs, Sahnūn could not go to Mālik bin Anas in order that he only learnt Mālikī school from the friends and followers of Imām Mālik. He returned to Qairawān in 191/806. Before he left to study Mālikī school, there were a number of thirty Qairawān scholars who all studied to Mālik directly about jurisprudences and fatwas. With the arrival of Sahnūn from Mashriq, he spread the idea of Mālikī school throughout Maghrib and became the most famous scholars there (Mahfūzu, 1994, III, p. 12-13). He became qāọī at $234 \mathrm{H}$ and died six years later (al-Ifrīqī, n.d., p, 101-104).

Book of al-Mudawwana as Șahnūn's work contained questions and answers on various issues of schools (Al-Șabbāgh, 2011, p. 180). In addition to the intellectual journey, the scholars of al-Andalus also made correspondence with Qairawān scholars on various problems. Ibn al-Faradī on his book, Tārīkh 'Ulamā' alAndalus, also mentioned repeatedly about the biography of scholars of al-Andalus who learnt from Șahnūn (Ibn al-Faraḍī, 2008). Qairawān became one path of intellectual journey because of geographical location, where it was the closest area to al-Andalus and the most advanced and knowledgeable in the Maghrib (AlȘabbāgh, 2011, p. 178-179)

\section{CONNECTION OF INTELLECTUAL NETWORKS IN AL-ANDALUS}

The intellectual networks of Shām, Iraq, Medina and Qairawān highlighted the formation of knowledge and culture in al-Andalus in $2 n d / 8$ th and $3 \mathrm{rd} / 9$ th century. This was period of knowledge formation as well as negotiation between ideology and power of knowledge. The hegemony of Mālikī as official school of alAndalus implemented the policy of jurists and theologians, namely Mālikī school and Sunnī theology. Scholars of Mālikī school, supported by Umayyad, gained authority to ban and censor schools and books that were inconsistent and incompatible with the Mālikī. Residents in al-Andalus under the authority of Mālikī only used the Qur'an and Muwațta' Mālik as the only reference of knowledge (al-Maqdisī, 1991, p. 236).

With such biased and unfair policies, Māliki scholars, approved by the emirs, forbade the entry of books brought from Iraq and also everything that disagreed with the Māliki school. This situation threatened nonMālikī scholars who were studying at Mashriq or had returned to al-Andalus. The scholars had to struggle to spread their ideas and writings, even if they were forbidden. For example Baqī bin Makhlad, as Shāfi'i followers, boycotted by the Maliki scholars such as Muhammad bin Waḍ̣̂ậ and Qāsim bin Așbagh. For the first, Baqī still spread his ideas and book brought from Mashriq. But he was reported by Mālikī scholars to Muhammad bin 'Abd al-Rahman bin al-Hakam because of disturbing the stability of the political, social and intellectual sphere. He was accused of spreading an unofficial school and Mâlikī school filed for him a detention. Emir Muhammad did not necessarily receive objections and complaints from Mālikī scholars. He invited Baqī and Mălikī school at a forum to test Baqīs knowledge. In the end, Baqi excelled in the forum and the emir ordered that he was allowed to keep on spreading his ideas. In addition, the books of Baqi and books which he brought from Iraq were included in the library's book list. However, Baqi was still provoked and permanently incited by Mālikī scholars after that (al-Marrākishī, 1983, II. p. 109-110).

In the 2nd/8th century until the beginning of the second half 3rd/9th century, Māliki schools in Africa were also suppressed by other school near al-Andalus (al-Marrākishī, 1983, I, p. 109). Abbasid made Hanafĩ as official school, thus Islamic region from Hijijāz to Africa controlled entirely with Hanafi school. The main scholar of Qairawān, Sahnnūn bin Sa'îd, at that time also suppressed by the Henanafi school ruled by Aghāliba descendants. Nevertheless, he still taught knowledge and became an intermediary for the scholars of alAndalus who want to learn Mālikī (al-Barmakī, 1900, V, p. 234-236; al-Dhahabī, 2003, X, p. 54-55). The rivalry between Mālikī in Maghrib and Hanafĩ schools in Mashriq influenced the study of Islamic knowledge, ranging from Qur'anic exegesis, hadith until jurisprudence. In the study of jurisprudence, scholars in alAndalus had to use Mālikī school in their daily life in order to avoid similarities with their rival in Mashriq. 


\section{SCHOOL NETWORKS AND STYLES OF KNOWLEDGE IN AL-ANDALUS}

The network of jurisprudence schools in al-Andalus determined the styles of knowledge study, the essay of the book and also the styles of thought. The entry of Māliki school to al-Andalus was influenced by political, emotional, socio-cultural and intellectual factors. Political factors that determine the dominance of Maliki in alAndalus was an opposition of Umayyad on his rivalry, Abbasid dynasty, which made Hanafi their official school. The emotional factor was caused by Mālik's tendency to the Umayyad and his dislike of Abbasid who hunted the descendants of the Prophet and wiped out the remnants of Umayyad family. Socio-cultural factors, as suggested by Ibn Khaldūn, were a rural community equation (badāwah) and the level of technology and knowledge between Hijāz and al-Andalus. Intellectual factor was similarity of textual thought between Hijāz and al-Andalus. Mālikī school in al-Andalus then affiliated with Medina and helped scholars of schools in the surrounding areas such as Qairawān (Akmaluddin, 2017).

In addition, Auzā'ī school was no longer becoming ideological and intellectual support. This school had already lost its authority and tradition when Umayyad dynasty in Mashriq collapsed and al-Auzā'i was considered in favor of Abbasid dynasty. Although for some time had been the official school of al-Andalus, Auzā'ī school had been replaced by stronger school and legitimized authority, namely Mālikī school. Auzā'ī school in Mashriq weakened and had powerless in the obstacle championed by Hanafi which supported by Abbasid and descendants of Aghāliba. However, Auzāiī school was closer to Mālikī with a little more developed and sophisticated knowledge (Watt \& Cachia, 1977, p. 64).

Auzā'ī school was wider and not so strong as Mālikī school by taking the opinion from unknown hadis, as well as mursal and maqțū' hadith in its book. For example planting trees inside jāmi mosque which according to Auzā'î school was allowed. But, it was not allowed by Maliki and his followers (Ibn al-Faraḍī, 2008, I, p. 278-279). Therefore, many mosques in Cordoba planted and surrounded by trees and fruits like olives, palm and orange to decorate mosques or shelter. It happened during the policy of Șa'șa'ah bin Sallām, as prominent scholar in Auzā'î school. These trees were seen on other areas such as al-Muriyya (Almeria) and Gharnāța (Granada). Other fruits were figs (tīn), apple, almond and others. Such mosque conditions were not found in Mashriq (Torres Balbás, 1945, p. 22). Sights like this also were not found when Mālikī became the official school in al-Andalus (al-Maqdisī, 1991, p. 236-237). However, figs, as staple food of the population in al-Andalus, became obligatory zakat. The involvement of the Mālikĩ as the official school of al-Andalus had a significant impact on the determination of Islamic knowledge. In regard to power relations and knowledge, Michel Foucault says that the power is not repressive, but productive (Shiner, 1982). This is evidenced by the standardization of schools for the strengthening of the basic religion of Islam and the unity of umma which the people of al-Andalus at that time needed the one and the whole knowledge. The societies were without religious intellectual knowledge and should be given a single and authoritative knowledge. For example scholars had their roles in dealing with various heresies that occurred in the midcentury 3rd/9th in al-Andalus such as acculturation with the local community, and other inter-religious marriages. Mālikī scholars later issued a stance on the dangers of heresy, threat, punishment and torment at the end of the day as written in the book of work of 'Abd al-Malik bin Habīo, Kitāb al-Ta'rīkh and al-Ghāya wa al-Nihāya. Muslim identity was also eroded by the Jews and the Christians who settled before. Scholars with the rulers of al-Andalus played an important role in defining identity, trust and community in social and religious dynamics (Safran, 2001).

A single and homogeneous knowledge was undertaken by al-Andalus scholars as a strategic move to base systematic and comprehensive knowledge. Thus, a time without knowledge of the community will move and become knowledgeable and civilized society. But it lasted so long that a single and authoritative knowledge became repressive and authoritarian. By this, many Mālikī scholars at the end of the 3rd/9th century were to manipulate previous scholars' opinions to reinforce fatwa and decisions that had been made (Hendrickson, 2013). They were then trapped in isolated knowledge and did not greet knowledge beyond the school. This led schools other Mālikī in al-Andalus were getting excluded and having to compete to deal with class conflict with the Mālikī scholars. They also had to compete in the fight for influence in the community, ulama and rulers.

The orthodoxy of knowledge by the Mālikī school at the end of the third/ninth century later dominated and replaced their authoritative and comprehensive school of thought in the second century. Therefore, the development of schools other than Mālikī was considered as a threat to their social status, positions and scientific authority. With the orthodoxy of Mālikī school, other Mālikī schools came and offered a new perspective of more knowledge that opened to be criticized and discussed. The emergence of scholars from Iraq such as Baqi bin Makhlad was considered as a new milestone in history, but was considered as an obstacle by Mālikī leaders. Baqī bin Makhlad, and who had same attitude with him, were considered to raise a critical awareness of the society of the actions of taqlīd and orthodoxy of Mālikĩ school. 
According to Maribel Fierro (1998, 2016), Mālikī scholars of al-Andalus Maliki will act in different ways on various books they do not like as sensors and control knowledge. For example by destroying or burning a book, deleting its contents, controlling access and writing a rejection book on an unwelcome book. Therefore, some of the books belonging to other Mālikī scholars like Baqī bin Makhlad such as Musnad, Mușannaf and his exegesis were not found until now. Thus, the figh schools in al-Andalus determined the tendentious and ideological pattern of knowledge. This trend will be countered by the class struggle and group of other schools so that they can be accepted as recognized and legitimized community (Al-Bukhtī, 2011; Kaddouri, 2012; Nūrī, 1983).

\section{CONCLUSION}

The origins of the jurisprudence school in al-Andalus in $2 \mathrm{nd} / 8$ th and $3 \mathrm{rd} / 9$ th century can be traced in the intellectual journey of the scholars. This journey is not only based on the existence of knowledge itself, but political, social, geographical and ideological factors are also influential in the journey. These factors ultimately determined the path chosen by the scholars of al-Andalus and then formed knowledge there when they returned from Mashriq. The relation of conflict between the jurisprudence schools in al-Andalus influenced other schools of knowledge, such as hadith and theology. This conflict was eventually won by Mālikī which fought Auzā'ī school as beginning school in al-Andalus. Victory of Mālikī school delivered to hegemony over other schools and became license authority and single tradition. With the influence of the power, they then acted banning and censoring schools that were not in accordance with the legal doctrine Maliki. However, it should be noted that initially the power was productive and unrepressive. By the time, the power of the Mālikī school was repressif, tendentious and authoritarian. They emphasized on reproduction and imitation of opinion to Mālikī school.

These circumstances led to conflicts with other schools, censorship and banning of the teaching, and also books and their knowledge. The opposition of Māliki later protested against the hegemony of intellectual and class struggle to keep reviewing their schools and spreading the books and the knowledge. This situation led to the arbitration of knowledge by the Umayyad emirs which eventually led to peace and agreement between the parties in conflict. However, the process of hegemony and counter-hegemony was ongoing process to the next centuries until the fall of Granada in 1429 which marked the end of the Islamic dynasty in alAndalus.

\section{ACKNOWLEDGEMENT}

This work was made possible by the funding from LPDP (Lembaga Pengelola Dana Pendidikan) scholarship of Indonesian Ministry of Finance. Grant sponsor did not assist in the development of the study design, collection of data, analysis and interpretation of data, the writing of the manuscript or the decision to submit the manuscript for publication.

\section{REFERENCE LIST}

Akmaluddin, M. (2017). Developments of Hadith Riwāya in Al-Andalus (2nd-3rd Centuries of Hijriyya). Ulumuna, 21(2), In Press.

al-Barmakī, A. bin M. I. K. (1900). Wafayāt al-A'yān Anbā’ Abnā' al-Zamān. (I. 'Abbās, Ed.). Beirut: Dār Șādir.

al-Ifrīqī, M. bin A. (n.d.). Ṭabaqāt 'Ulamā' Ifrīqiyyah. Beirut: Dār al-Kitāb.

al-Ishbīlī, 'Abd al-Raḥmān bin Muḥammad Ibn Khaldūn. (1988). Dīwān al-Mubatada' wa al-Khabar fĩ Tārīkh al-'Arab wa al-Barbar wa man 'Āṣarahum min Dhawī al-Sha'n al-Akbar. (K. Shahāda, Ed.). Beirut: Dār al-Fikr.

al-Maqdisī, M. bin A. (1991). Ahsan al-Taqāsīm fị Ma'rifa al-Aqālīmm. Kairo: Mațba'ah al-Madbūlī.

al-Marrākishī, M. bin M. I. 'Idhārī. (1983). al-Bayān al-Mughrib fĩ Akhār al-Andalus wa al-Maghrib. (G. S. Colin \& E. L. Provencal, Eds.). Beirut: Dār al-Thaqāfah.

al-Dhahabī, M. bin A. (2003). Tārīkh al-Islām wa Wafayāt al-Mashāhīr wa al-A lām. (B. 'Awwād Ma'rūf, Ed.). Tunis: Dār al-Gharb al-Islāmī.

Al-Bukhtī, J. 'Ilāl. (2011). al-Madrasa al-'Aqdiyya al-Ūlā bi al-Andalus baina Ahl al-Fiqh wa Ahl al-Ḥadīth (pp. 
161-205). Presented at the Buhūth al-Nadwa al-'Ilmiyya al-Ūlā al-Madrasa al-Hadīthiyya bi al-Maghrib wa al-Andalus: al-Imām Ibn al-Qatțān Namūdhajan, Markaz Ibn al-Qațțān li al-Dirāsāt wa al-Abḥāth fi al-Ḥadīth al-Sharīf wa al-Sīrah al-'Ițrah, Maroko: al-Rābița al-Muḥammadiyya li al-'Ulamā.'

Al-Maqqarī, A. bin M. (1997). Nafh̆ al-Țīb min Ghusn al-Andalus al-Rațīb wa Dhikr Wazīiihā Lisān al-Dīn bin al-Khațīb. (I. 'Abbās, Ed.). Beirut: Dār Șādir.

Al-Ṣabbāgh, L. 'Izz al-Dīn. (2011). al-Qairawān Multaqā al-Andalusiyyīn. Majalla Al-Tarbiya Wa Al-'Ilm, 18(4), 172-1193.

Amīn, A. (2012). ZZuhr al-Islām. Kairo: Mu'assasa Hindāwī li al-Ta‘līm wa al-Thaqāfa.

'Asākir, 'Alī bin al-Ḥasan Ibn. (1995). Tārikh Dimashq. ('Amr bin Gharāmah al-'Amrawī, Ed.). Beirut: Dār alFikr.

Dutton, Y. (2000). The Origins of Islamic Law: The Qur'an, the Muwatța' and Madinan 'Amal. New Delhi: Lawman.

Fierro, M. (1998). Manuscritos en Al-Andalus: El proyecto HATA (Historia de los Autores y Transmisores Andalusíes). Al-Qanțara, 19(2), 473-501.

Fierro, M. (2011). Local and Global in Hadith Literature: The Case of Al-Andalus. In N. B. der Voort, K. Versteegh, \& J. Wagemakers (Eds.), The Transmission and Dynamics of the Textual Sources of Islam: Essays in Honour of Harald Motzki (pp. 63-88). London: Brill.

Fierro, M. (2016). How Do We Know about the Circulation of Books in al-Andalus? The Case of al-Bakrî's Kitāb al-Anwār. Intellectual History of the Islamicate World, 4(1-2), 152-169. https://doi.org/10.1163/2212943X-00401009

Hendrickson, J. (2013). Is al-Andalus Different? Continuity as Contested, Constructed, and Performed across Three Mālikī Fatwās. Islamic Law and Society, 20(4), 371-424. https://doi.org/10.1163/15685195-0204P0002

Hourani, G. F. (1970). The Early Growth of the Secular Sciences in Andalusia. Studia Islamica, (32), 143156.

Ḥusain, K. 'Ajīl. (2007). al-Tamhīd li al-Tadwīn al-Tārikhī fĩ al-Andalus ḥattā Nihāya al-Qarn al-Thānī al-Hijrī. Majalla Jāmi‘a Tikrīt Li Al-'Ulūm Al-Insāniyya, 14(11), 185-226.

Ibn al-Faraḍī, 'Abd Allāh bin Muhammad. (2008). Tārīkh 'Ulamā' al-Andalus. (B. 'Awwād Ma'rūf, Ed.). Tunis: Dār al-Gharb al-Islāmī.

Kaddouri, S. (2012). Refutations of Ibn Hazm by Mālikī Authors from al-Andalus and North-Africa, 539-599. https://doi.org/10.1163/9789004243101_021

Maḥfūz, M. (1994). Tarājum al-Mu'allifiñ al-Tūnisiyyīn. Beirut: Dār al-Gharb al-Islāmī.

Masud, M. K. (1991). A History of Islamic Law in Spain: An Overview. Islamic Studies, 30(1/2), 7-35.

Nūrī, M. (1983). Muhammad bin Waḍ̣āḥ al-Qurțubī Mu’assis Madrasa al-Hadīth bi al-Andalus ma‘a Baqī bin Makhlad. Ribāț: Al-Maktaba al-Ma'ārif.

Öztoprak, M. (2013a). Endülüs hadisçiliğinde kadıların yeri. Şırnak Üniversitesi Illahiyat Fakültesi Dergisi, 1(7). Retrieved from http://dergipark.ulakbim.gov.tr/sirnakifd/article/view/5000109747

Öztoprak, M. (2013b). Hadis İlminin Endülüs'e Girişi. Şırnak Üniversitesi Illahiyat Fakültesi Dergisi, 2, 143163.

Raisuddin, A. N. M. (1991). Baqī Ibn Makhlad Al-Qurțubī (201-276/816-889) and His Contribution to the Study of Hadīth Literature in Muslim Spain. Islamic Studies, 31(1), 263-270.

Raisuddin, A. N. M. (1992). Yahyyā Ibn Yahyyā al-Mașmūdī (152-234/769-851): His Contribution to the Study of Hadīth Literature in Spain. Islamic Studies, 30(2), 213-217.

Rozi, A. I. (1983). The Social Role of Scholars ('Ulama') in Islamic Spain: A Study of Medieval Biographical Dictionaries (Trājim) (Ph.D). Boston University Graduate School, Boston.

Safran, J. M. (2001). Identity and Differentiation in Ninth-Century al-Andalus. Speculum, 76(3), 573-598.

Shiner, L. (1982). Reading Foucault: Anti-Method and the Genealogy of Power-Knowledge. History and Theory, 21(3), 382-398. 
IJASOS- International E-Journal of Advances in Social Sciences, Vol. III, Issue 9, December 2017

Torres Balbás, L. (1945). Notas sobre Sevilla en la época musulmana. Al-Andalus, X, 177-196.

Watt, W. M., \& Cachia, P. (1977). A History of Islamic Spain. Edinburgh: Edinburgh University Press. 